\title{
Intestinal lesions in pigs affected with postweaning multisystemic wasting syndrome ${ }^{1}$
}

\author{
Priscila Zlotowski², André M.R. Corrêa ${ }^{2}$, David E.S.N. Barcellos ${ }^{3}$, Cláudio E.F. \\ Cruz $^{2}$, William Asanome ${ }^{3}$, Aline Fernandes Barry ${ }^{4}$, Amauri Alcindo Alfieri ${ }^{4}$ and \\ David Driemeier ${ }^{2 *}$
}

\begin{abstract}
Zlotowski P., Corrêa A.M.R., Barcellos D.E.S., Cruz C.E.F., Asanome W., Barry A.F., Alfieri A.A. \& Driemeier D. 2008. Intestinal lesions in pigs affected with postweaning multisystemic wasting syndrome. Pesquisa Veterinária Brasileira 28(6):313-318. Departamento de Patologia Clinica Veterinária, Faculdade de Medicina Veterinária, Universidade Federal do Rio Grande do Sul, Av. Bento Gonçalves 9090, Porto Alegre, RS 91540-000, Brazil. E-mail: davetpat@ufrgs.br

Samples of mesenteric lymph nodes and intestines from 79 unthrifty 3- to 5-monthold postweaning pigs, confirmed as naturally affected with postweaning multisystemic wasting syndrome (PMWS), were studied. Pigs originated from 12 farms in southern Brazil and were selected on the basis of clinical signs and/or gross lesions suggestive of enteric disorder. Lymphohistiocytic infiltrates of varying intensity were associated with anti-porcine circovirus type 2 (anti-PCV2) immunostaining (IS) in samples of intestines and mesenteric lymph nodes from all pigs. Although most findings were similar to those described in PCV2-associated enteritis, anti-PCV2 IS in association with depletion of the goblet cell mucin stores (24 pigs), diffuse ileal villous atrophy and fusion (18 pigs), and dilatation of the lymphatic vessels (11 pigs) combined or not with lymphangitis were also observed. PCV2 antigen was immunohistochemically demonstrated in the cytoplasm and nuclei from intralesional epithelial cells, histiocytes, and endothelial-like cells in intestinal tissues. Together these findings imply an association with PCV2. The presence of co-infections by Lawsonia intracellularis, Brachyspira spp., Mycobacterium spp., Salmonella spp., rotavirus, parvovirus, coronavirus and enteric calicivirus with PCV2 in the intestinal lesions was investigated.
\end{abstract}

INDEX TERMS: Circovirus, co-infections, enteric lesions, PCV2, PMWS.

RESUMO.- [Lesões entéricas em suínos afetados por síndrome multissistêmica do definhamento dos suínos.] Amostras de linfonodos mesentéricos e intestinos de 79 leitões desmamados refugos, entre 3 e 5 meses de idade e confirmados como naturalmente afetados pela síndrome

\footnotetext{
${ }^{1}$ Received on February 21, 2008.

Accepted for publication on April 4, 2008.

2 Departamento de Patologia Clinica Veterinária, Faculdade de Medicina Veterinária, Universidade Federal do Rio Grande do Sul (UFRGS), Av. Bento Gonçalves 9090, Porto Alegre, RS 91540-000, Brazil. ${ }^{*}$ Corresponding author: davetpat@ufrgs.br

${ }^{3}$ Departamento de Medicina Animal - Suínos, Faculdade de Medicina Veterinária, UFRGS. E-mail: setorsuinos@yahoo.com.br

${ }^{4}$ Laboratório de Virologia Animal, Departamento de Medicina Veterinária Preventiva, Universidade Estadual de Londrina, Cx. Postal 6001, Londrina, PR 86051-990, Brazil. E-mail: alfieri@uel.br
}

multissistêmica do definhamento foram estudadas. Os suínos eram oriundos de 12 criações no sul do país e foram selecionados em função dos sinais clínicos e/ou lesões macroscópicas sugestivos de doença entérica. Infiltrados linfoistiocíticos de intensidades variáveis foram associados com marcação positiva anti-circovirus suíno tipo 2 (antiPCV2) em amostras de intestinos e linfonodos mesentéricos de todos os 79 animais. Embora a maioria dos achados fossem semelhantes aos descritos em enterite associada com PCV2, marcação imuno-histoquímica anti-PCV2 foi associada com depleção de células caliciformes (24 suínos), atrofia e fusão de vilosidades do íleo (18 suínos) e dilatação de vasos linfáticos (11 suínos) combinada ou não com linfangite. Antígenos de PCV2 foram demonstrados por imuno-histoquímica no citoplasma e núcleo de células epiteliais intralesionais, histiócitos e células tipo endotelial 
em tecidos intestinais. Em conjunto, esses resultados sugerem que as lesões estavam associadas com PCV2. A presença de co-infecções por Lawsonia intracellularis, Brachyspira spp., Mycobacterium spp., Salmonella spp., rotavírus, parvovírus, coronavírus e calicivírus entérico com PCV2 nas lesões intestinais foi investigada.

TERMOS DE INDEXAÇÃO: Circovírus, co-infecções, lesões entéricas, PCV2, SMDS.

\section{INTRODUCTION}

Porcine circovirus type 2 (PCV2) infections have been associated with many different clinical syndromes (Clark 1997, Allan \& Ellis 2000, Opriessnig et al. 2006, Segalés \& Domingo 2002), among which postweaning multissystemic wasting syndrome (PMWS) has caused the greatest economic losses to the swine industry. The disease is confirmed by the demonstration of PCV2 antigen or nucleic acids in association with characteristic microscopic lesions (Sorden 2000) such as Iymphocyte depletion and histiocytic to granulomatous inflammation in lymphoid tissues and certain organs (Clark 1997, Rosell et al. 1999, Segalés \& Domingo 2000).

Cases of swine enteritis have been associated with PCV2 alone (Kim et al. 2004b, Segalés et al. 2004, Jensen et al. 2006) or combined with other organisms (Carrasco et al. 2000, Segalés et al. 2001, Ha et al. 2005, Jensen et al. 2006). While substantial information has been presented on the pathogenesis of a number of enteric pathogens of pigs (Hampson \& Trott 1999, Schwartz 1999, Lawson \& Gebhart 2000), the importance and the involvement of some of these organisms in enteric disorders of PMWS-affected pigs remains to be clarified. This communication describes PCV2-associated enteric lesions in PMWS-affected pigs.

\section{MATERIALS AND METHODS}

This study included 79 non-thriving 3 to 5 -month-old postweaning pigs confirmed as PMWS cases (Sorden 2000) that were selected on the basis of clinical signs or gross findings suggestive of intestinal disease (Table 1). Animals were necropsied immediately after euthanasia and originated from 12 herds in Rio Grande do Sul, Brazil. Fragments from mesenteric lymph nodes, jejunum, ileum, colon, and cecum were collected. Formalin fixed paraffin embedded samples of tissues were examined by hematoxylin and eosin and immunostaining (IS). Sections were processed for IS anti-PCV2 (Department of Veterinary Diagnostic and Production Animal Medicine, lowa State University, USA, Sorden et al. 1999) by the streptavidin-biotin immunoperoxidase (Dako, Carpinteria, $\mathrm{CA}$ ) technique using diaminobenzidine (Dako, Carpinteria, CA)

Table 1. Summary of gross changes in the intestines and mesenteric lymph nodes from 79 PMWS-affected pigs

\begin{tabular}{lcc}
\hline \multicolumn{1}{c}{ Gross lesion } & Frequency & $\%$ \\
\hline Enhanced mesenteric lymph nodes & 56 & 70.9 \\
Necrotizing enteritis & 24 & 30.4 \\
Mesenteric edema & 20 & 25.3 \\
Lymphangiectasy & 15 & 18.9 \\
Thickened ileal mucosa & 5 & 6.3
\end{tabular}

as chromogen. Similarly, selected sections were also tested by IS against Lawsonia intracellularis (Department of Veterinary Pathobiology, University of Minnesota, USA, Guedes et al. 2002), Brachyspira spp. (Centro de Pesquisas Veterinárias Desidério Finamor, Eldorado do Sul, Brazil, Paulovich et al. 2004), Mycobacterium spp. (GeneTex Inc., Texas, USA, Radhakrishnan et al. 1991), Salmonella spp. (Biogenesis Inc., Kingston, USA, Schauser et al. 2004), porcine parvovirus (VMRD Inc., Pullman, USA, Kim \& Chae 2004), and porcine coronavirus (Serotec, Whashington, USA). Selected fecal samples $(n=12)$ were also screened for the presence of rotavirus groups $A, B$ and $C$, and enteric calicivirus (Norovirus and Sapovirus genera) by reverse transcription polymerase chain reaction (RT-PCR) assay. The viral nucleic acid was extracted from $10 \%$ to $20 \%$ (w/v) fecal suspensions in PBS according to Alfieri et al. (2006) followed by RT-PCR with specific primers for $G$ and $P$ genotypes of group A (Gouvea et al. 1990, Gentsch et al. 1992); group B, which also included a second round of amplification (semi-nested PCR) (Gouvea et al. 1991); and group C (Alfieri et al. 1999). The RTPCR for enteric calicivirus was performed in accordance to Barry et al. (2008) with primers described by Jiang et al. (1999) that detect norovirus and sapovirus strains. All amplicons were analyzed by electrophoresis in ethidium bromide stained $2 \%$ agarose gel and visualized under UV light. Double IS for simultaneous demonstration of PCV2 and cytokeratin (Dako, Carpinteria, CA) was applied with diaminobenzidine (Dako, Carpinteria, CA) and alkaline phosphatase (Dako, Carpinteria, $\mathrm{CA})$ as chromogens, respectively. In addition, selected sections were anti-PCV2 immunostained and counterstained with Alcian blue pH 2.5 and hematoxylin (Gaffney 1992). Cecal and colonic samples were submitted for bacteriological examinations, which included testing for Salmonella spp. (Carter et al. 1995), Escherichia coli (Barrow \& Feltham 1993) and Brachyspira spp. (Hampson \& Trott 1999). Fragments from intestines were preserved in glutaraldeide $2 \%$ for scanning electron microscopy. Finally, Ziehl-Neelsen staining was performed on selected samples.

\section{RESULTS}

Diarrhea was observed in 34 pigs and a total of 56 pigs had at least one gross change in the intestines or mesenteric lymph nodes (Fig.1). The macroscopic findings are summarized in Table 1. Microscopic lesions in the Peyer's patches included lymphoid depletion, histiocytosis, and occasionally necrosis. Areas with atrophy and fusion of the ileal villi were associated with lymphohistiocytic infiltrates (lamina propria) and anti-PCV2 IS, the latter in samples from 18 pigs. Atrophy of villi combined with decreased intestinal mucin stores were frequent findings. Multinucleated giant cells were often seen within the lamina propria and Peyer's patches of the small intestines. Mucosal necrosis ranged from focal and superficial epithelial desquamation to extensive ulceration, frequently reaching the submucosa. Necrotic changes were more severe in large than small intestines. Fibrin and neutrophils were seen exuding from abscesses in necrotizing crypts to the mucosal lumen. Epithelial cells from the abscessing or necrotizing crypts were also associated with anti-PCV2 IS. Enlarged submucosal lymphatic vessels were associated with antiPCV2 IS (Fig. 2) in samples from 11 pigs, but occasionally 


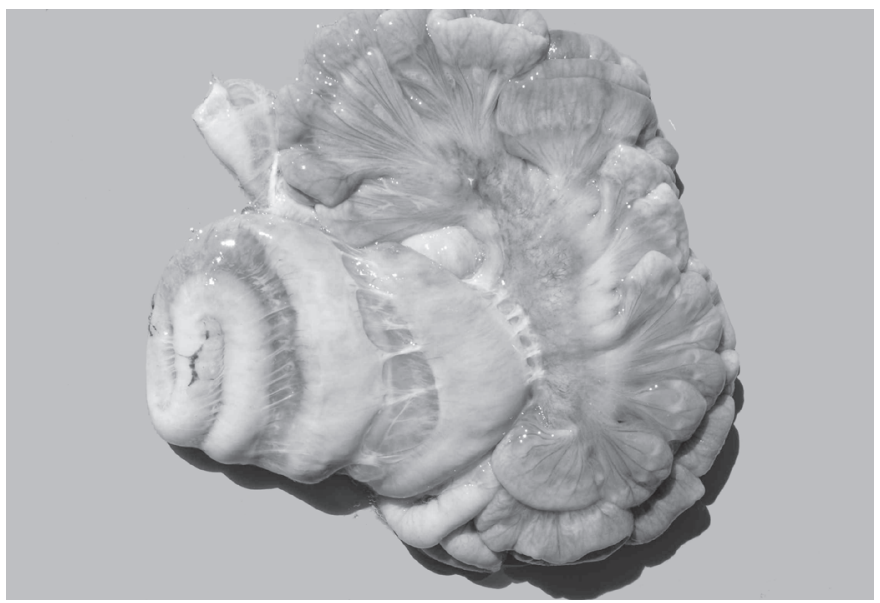

Fig.1. Pig naturally affected by PMWS. Intestine with mesenteric edema and enlarged mesenteric lymph nodes.

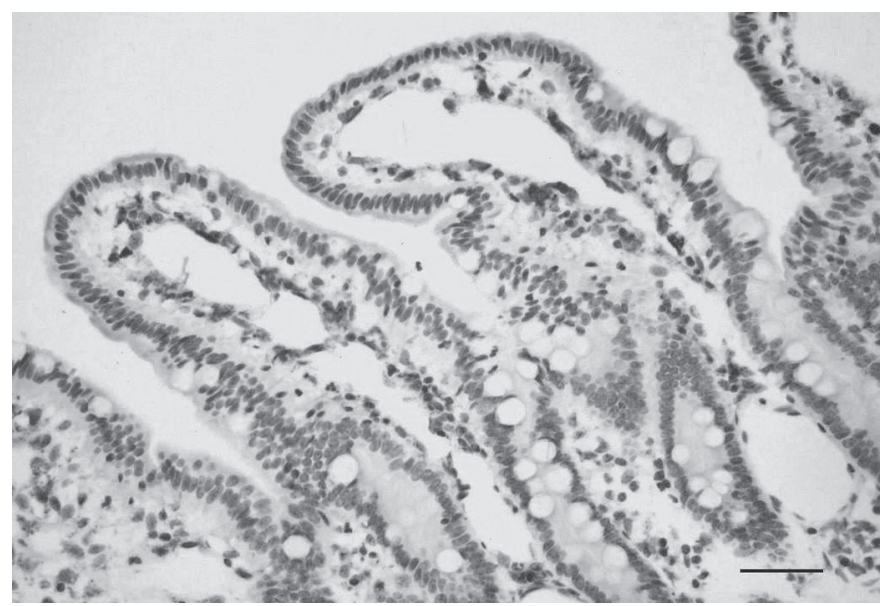

Fig.2. Pig naturally affected by PMWS. Small intestine. Dilatated lymphatic vessel (central lacteal) associated with PCV2immunolabelling in endothelial-like cells. Streptavidin-biotin immunoperoxidase. Bar: $40 \mu \mathrm{m}$

Table 2. Summary of the microscopic intestinal lesions observed in 79 PMWS-affected pigs

\begin{tabular}{|c|c|c|c|c|}
\hline \multirow[t]{2}{*}{ Lesion } & \multicolumn{2}{|c|}{ Small intestine } & \multicolumn{2}{|c|}{$\underline{\text { Large intestine }}$} \\
\hline & Frequency & $\%$ & Frequency & $\%$ \\
\hline Lymphohistiocytic infiltrate (PP) & 64 & 81.0 & NA & - \\
\hline Lymphoid depletion (PP) & 26 & 32.9 & NA & - \\
\hline Giant cells (PP) & 12 & 15.2 & NA & - \\
\hline Intracytoplasmic inclusion bodies (PP) & 19 & 24.1 & NA & - \\
\hline Centrofolicular necrosis (PP) & 10 & 12.6 & NA & - \\
\hline Lymphohistiocytic infiltrate in mucosa & 45 & 56.9 & 41 & 51.9 \\
\hline Intracytoplasmic inclusion bodies in mucosa & 3 & 3.8 & 4 & 5.1 \\
\hline Depletion of goblet cells mucin stores & 32 & 40.5 & NA & - \\
\hline Villous atrophy & 27 & 34.2 & NA & - \\
\hline Lymphatic vessel dilatation & 25 & 31.6 & 12 & 15.2 \\
\hline Lymphangitis & 14 & 17.7 & 7 & 8.9 \\
\hline Edema in mucosa and submucosa & 17 & 21.5 & 39 & 49.4 \\
\hline Giant cells in mucosa & 16 & 20.2 & 4 & 5.1 \\
\hline Dilatation and abscesses in crypts & 8 & 10.1 & 28 & 35.4 \\
\hline Mucosal necrosis & 7 & 8.9 & 29 & 36.7 \\
\hline
\end{tabular}

PP: Peyer's patches, NA: not analyzed. with severe mononuclear infiltration. Anti-PCV2 immunostained histiocytes were also seen in association or not with mononuclear infiltration in the lumen of dilated lymphatic vessels. Multiple intracytoplasmic inclusions bodies were observed mostly in the Peyer's patches, but also in the mucosa of a few cases. Lymphohistiocytic infiltrate (79/79), Iymphoid depletion (25/79), Iymphangiectasy (26/79), lymphangitis (12/79), giant cells (10/79), multifocal necrosis (12/79), and intracytoplasmic inclusion

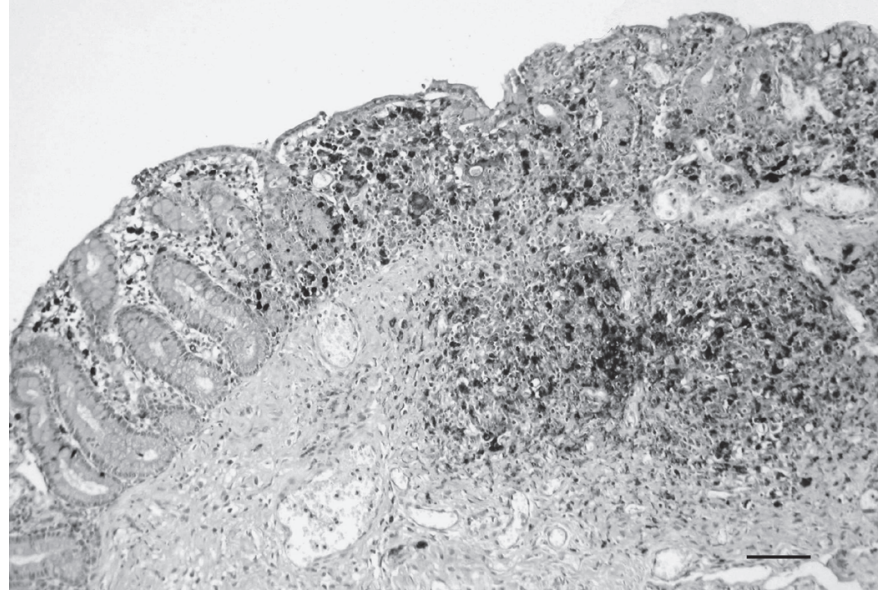

Fig.3. Naturally PMWS affected pig. Small intestines. Villous atrophy and focal depletion of acid mucin stores in goblet cells associated with PCV2 immunoreactivity within histiocytes and epithelial cells of the mucosa, and in the Peyer's patche. Streptavidin biotin immunoperoxidase counterstained with Alcian blue and hematoxylin. Bar: $60 \mu \mathrm{m}$

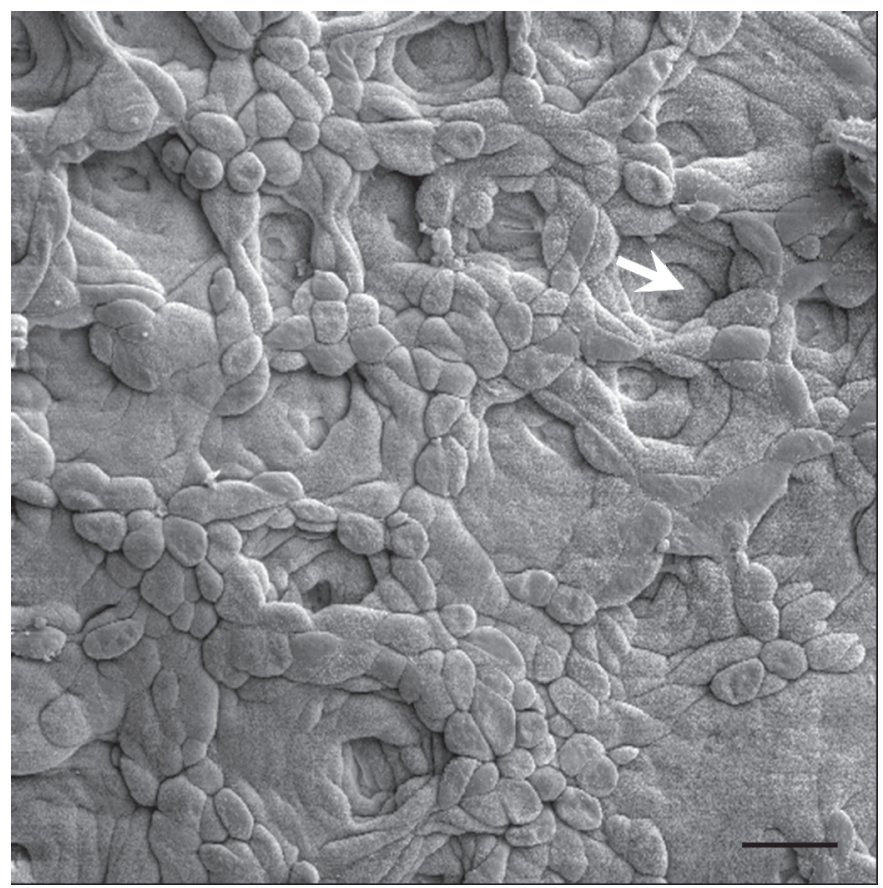

Fig.4. Electron micrography of the ileal mucosa of a naturally PMWS-affected pig. Villous atrophy and shallow crypts

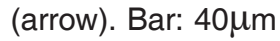


bodies (8/79) were seen in the mesenteric lymph nodes. The main microscopic findings observed in intestinal samples are presented in Table 2.

All the 79 pigs had microscopic changes and anti-PCV2 IS in samples of both intestines and mesenteric lymph nodes. Anti-PCV2 IS was seen in Peyer's patches (53/79), histiocytes (lamina propria) within the ileal (33/79) and colonic (29/79) mucosa, in epithelial cells from ileal $(6 / 79)$ and colonic (15/79) crypts and endothelial-like cells of the ileal (11/79) and colonic (5/79) lymphatic vessels. Lawsonia intracellularis IS was observed in the apical cytoplasm of epithelial cells from ileal crypts in 1 out of 32 cases with depletion of mucin stores. Anti-Brachyspira spp. IS was seen bordering colonic crypts close to focal areas of necrosis in 2 out of 29 samples with necrotic changes. Anti-Salmonella spp. IS was observed in 17 of the 29 samples of necrotizing colitis. In contrast, Salmonella spp. was cultured from samples of 7 of these 29 with necrotic changes. Imunostaining against Mycobacterium spp., porcine parvovirus (PPV), and porcine coronavirus resulted negative in 20 (with giant cells), 7 (with necrosis in ileal mucosa), and 27 (with villous atrophy) intestinal samples, respectively. Double IS anti-PCV2 and cytokeratin confirmed the presence of PCV2 within epithelial cells in ileal and colonic samples. Anti-PCV2 IS counterstained with Alcian blue demonstrated the PCV2 antigens in association with evident depletion of the goblet cells acid mucin stores (Fig. 3) in samples from 24 pigs. Controls for the intestinal mucin stores were ileal sections from pigs confirmed as free from both PCV2 and Lawsonia intracellularis infections. Scanning electron microscopy detailedly illustrated the shallow crypts (Fig. 4) and

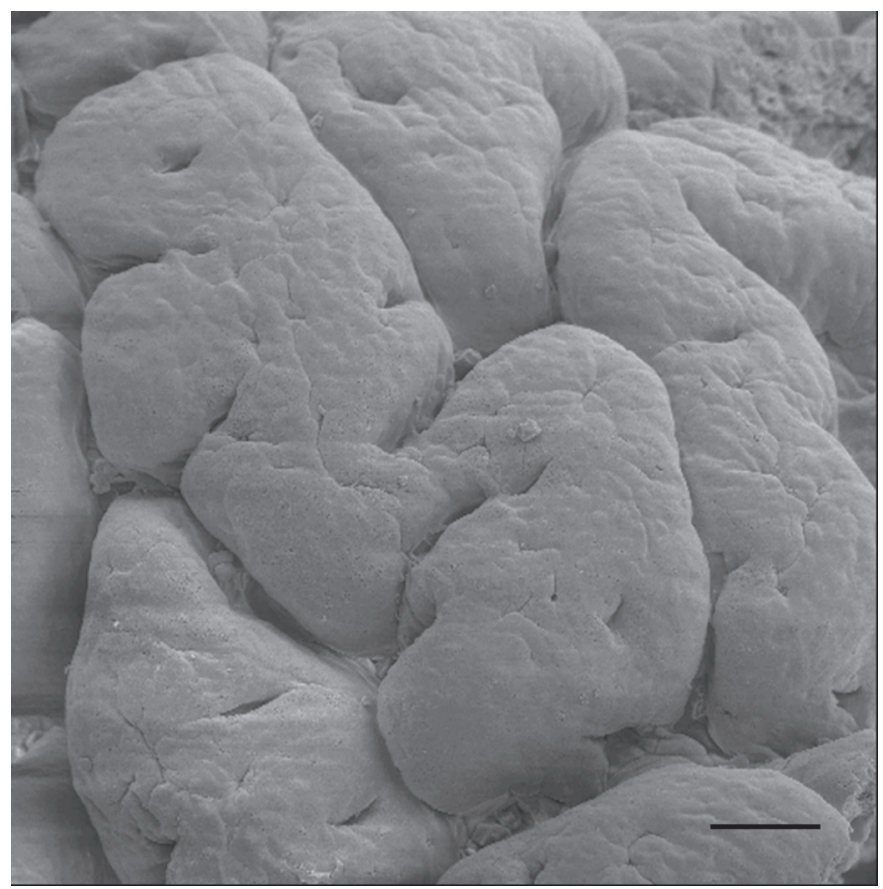

Fig.5. Electron micrography of the ileal mucosa of a naturally PMWS-affected pig. Severe villous atrophy. Observe flattened, fused, and widened villi. Bar: $10 \mu \mathrm{m}$
Table 3. Bacterial isolates in intestinal samples from 79 PMWS-affected pigs

\begin{tabular}{ccc}
\hline Bacteria & Frequency & $\%$ \\
\hline Escherichia coli & 5 & 6.3 \\
Brachyspira spp. & 4 & 5.1 \\
Salmonella spp. & 7 & 11.4
\end{tabular}

Table 4. Detection of enteric rota- and calicivirus in fecal samples of 12 PMWS-affected pigs with diffuse ileal villous atrophy and fusion by PCR (RT-PCR; SN-PCR) techniques

\begin{tabular}{ccccccc}
\hline \multirow{2}{*}{ Sample } & \multicolumn{3}{c}{ Rotavirus group } & & \multicolumn{2}{c}{ Calicivirus } \\
\cline { 2 - 5 } & A & B & C & & Sapovirus & Norovirus \\
\hline 1 & - & - & - & + & - \\
2 & - & - & - & - & - \\
3 & - & - & - & - & - \\
4 & - & - & + & + & - \\
5 & - & - & - & + & - \\
6 & - & - & + & - & - \\
7 & - & - & + & - & - \\
8 & - & - & - & - & - \\
9 & + & - & + & - & - \\
10 & - & - & - & + & - \\
11 & - & + & - & + & - \\
12 & + & - & + & + & -
\end{tabular}

atrophied and fused villi (Fig. 5). Table 3 includes the results of bacteriological examinations and Table 4 shows PCR results on rotavirus and enteric calicivirus detected in fecal samples from 12 out of 27 pigs with villous atrophy.

\section{DISCUSSION}

Although an unspecific sign of enteric dysfunction, diarrhea has been a common feature in PMWS and was present in 34 pigs. Lymphohistiocytic enteritis and anti-PCV2 IS were observed in intestinal samples from all 79 pigs. Most of the PCV2-associated enteric lesions described here were similar to those reported previously (Kim et al. 2004, Segalés \& Domingo 2004, Jensen et al. 2006); however, this report includes additional features in PCV2-associated intestinal changes in PMWS naturally affected pigs. A number of diseases have been associated with swine enteritis. Porcine proliferative enteropathy (PPE), swine dysentery and porcine colonic spirochetosis caused by Brachyspira spp., colibacillosis, and porcine salmonellosis are some of the most common bacterial diarrheal diseases of growing to finishing pigs (Moxley \& Duhamel 2004).

PPE caused by Lawsonia intracellularis is also associated with unthriftness, retarded growth, wasting, and diarrhoea in pigs, but it was detected in only one pig. The absence in most sections of $L$. Intracellularis infection, an initial suspicion and a plausible explanation for the decreased goblet cell mucin stores (Lawson \& Gebhart 2000, Driemeier et al. 2002) motivated further investigation. Depletion of goblet cell acid mucin stores were demonstrated in association with consistent PCV2 immunolabelling in intestinal samples from 24 pigs by the combination of anti- 
PCV2 immunostaining with Alcian blue counterstaining. Combined staining methods have been reported as useful for studying simultaneously pathogenic agents and the microscopic changes induced by them (Genta et al. 1994, Driemeier et al. 2002). The cause of the decreasing of the goblet cell mucin stores reported here is unknown. The possibility that some of these cases with depletion of mucin stores in goblet cells were previously chronically infected with Lawsonia intracellularis can not be excluded. Physiological responses of goblet cells to intestinal insults are poorly defined; however, it has been suggested that intestinal microbes may affect goblet cell dynamics directly via the local release of bioactive factors or indirectly via activation of host immune cells (Deplancke \& Gaskins 2001). Intestinal parasites were not observed in this study.

Rota- and coronavirus are worldwide causes of neonatal gastrenteric disease of pigs (Herbst et al. 1989, Paul \& Stevenson 1999). Villous atrophy has commonly been linked to coronavirus infection (Barker et al. 1993), which usually occurs at a younger age. Areas with atrophied and fused villi were observed in samples from 27 pigs, most of which also correlated with anti-PCV2 IS; however, anti-coronavirus labelling was not seen and rotavirus was detected by PCR in fecal samples of 4 between 12 from these 27 pigs. Serogroups of rotavirus have been detected isolately and as mixed infections in pigs with and without clinical signs of enteric disorder (Alfieri et al. 1999, Barry et al. 2008). Similar situations have been reported on porcine enteric caliciviruses (Kim et al. 2006, Martinéz et al. 2006). Again, the participation of these agents in association or not with PCV2 in some cases described here can not be ruled out. The role of such co-infections in pigs as well as its association with intestinal lesions and diarrhea in infected pigs is still not clear (Wang et al., 2006).

Shallow crypts and flattened, fused, and widened villi were evidenced by electron microscopy and were probably associated with edema, lymphatic distension and lymphohistiocytic infiltrate. Lymphangiectasy, which has already been associated with PMWS (Clark 1997), was observed in intestinal samples from 25 pigs and correlated with antiPCV2 IS in samples from 11 pigs. The cause of lymphatic dilatation is often unknown, but it is assumed to be subsequent to drainage difficulties, which might be linked to the lymphangitis seen in these cases, similarly as it may occur in Johne's disease. Granulomatous lymphadenitis and enteritis caused by Mycobacterium spp. were diagnostic possibilities excluded by negative results in Ziehl-Neelsen and anti-Mycobacterium IS methods. In addition, pigs in this study originated from herds previously tested negative for antibodies against classical swine fever.

Brachyspira spp., which may cause diffuse catarrhal and hemorrhagic or fibrinonecrotic colitis (Moxley \& Duhamel 1999) was bacteriologically detected as concurrent infection in 4 cases of PCV2-associated enteritis, 2 of which also showed anti-Brachyspira IS in samples with focal areas of necrosis. Varying degrees of necrotizing enteritis were seen in samples from 29 PMWS-affected pigs, of which 17 were immunohistochemically confirmed as co-infected with Salmonella spp. Necrotizing enteritis has typically been linked to swine salmonellosis (Schwartz 1999), but also has been described in PCV2 infection (Kim \& Chae 2004, Segalés et al. 2004, Jensen et al. 2006). Necrotizing enteritis has also been linked to porcine parvovirus (Duhamel et al. 1991), but anti-PPV IS was not observed. When present, lesions in swine enteric colibacillosis may be somewhat mild and unspecific, and may include coliform bacteria adhered to the villous epithelium and mucosal neutrophilic infiltration (Moxley \& Duhamel 1999). Although especially the former of these changes was not seen, E. coli was detected coinfecting with PCV2 the intestines from 5 pigs. Concurrent infections have frequently been associated with PCV2enteritis (Carrasco et al. 2000, Segalés et al. 2001, Ha et al. 2005, Jensen et al. 2006). In total, bacterial and viral coinfections with PCV2 were identified respectively in samples from 27 and 8 out of the 79 pigs, confirming that concurrent infections are expected in PMWS.

Except for the reasonable hypothesis that necrotizing colitis may be caused by Salmonella spp. (Schwartz 1999), PCV2 (Segalés et al. 2004, Jensen et al. 2006), or both together, the extent to which the lesions described above might be attributed to the bacteria studied, or even to others organinsms not included here remains unknown. The same applies to the viruses studied and the other changes described here. Moreover, it cannot be ruled out that the presence of PCV2 and the aforementioned changes were independent. However, the consistent PCV2 immunolabelling associated with characteristic (Clark 1997, Kim et al. 2004, Segalés et al. 2004, Jensen et al. 2006), and additional microscopic lesions was indicative that PCV2 may be involved in the pathogenesis of the intestinal lesions described here. Lesions such as villous atrophy, lymphangiectasy, and lymphohistiocytic infiltrates in intestinal tissues could comprehensively be associated with low rates of assimilation and digestion, which may certainly lead animals to the retarded growth and desnutrition usually seen in PMWS-affected pigs.

Acknowledgements.- This work was supported by grants from the Coordenação de Aperfeiçoamento de Pessoal de Nível Superior (CAPES) and Conselho Nacional de Desenvolvimento Científico e Tecnológico (CNPq), Brazil. Authors are also grateful to Dr. Severo Sales de Barros, from the Department of Veterinary Pathology, UFPel, for technical assistance.

\section{REFERENCES}

Alfieri A.A., Leite J. P.G., Alfirei A.F., Jiang B., Glass R.I. \& Gentsch J.R. 1999. Detection of field isolates of human and animal group C rotavirus by reverse transcription-polymerase chain reaction and digoxigenin-labeled oligonucleotide probes. J. Virol. Meth. 83:3543.

Alfieri A.A., Parazzi M.E., Takiuchi E., Médici K.C. \& Alfieri A.F. 2006. Frequency of group A rotavirus in diarrhoeic calves in Brazilian cattle herds, 1998-2002. Trop. Anim. Health Prod. 38:521-526.

Allan G.M. \& Ellis J.A. 2000. Porcine circoviruses: a review. J. Vet. Diag. Invest. 12:3-14.

Barker I.K., Van Dreumel A.A. \& Palmer N. 1993. Enteric coronavirus 
infection, p.184-190. In: Jubb K.V.F., Kennedy P.C. \& Palmer N. (ed.), Pathology of Domestic Animals. Academic Press, San Diego, CA.

Barry A.F., Alfieri A.F. \& Alfieri A.A. 2008. Detection and phylogenetic analysis of porcine enteric calicivirus, genetically related to the Cowden strain of sapovirus genogroup III, in Brazilian swine herds. Braz. J. Vet. Res. Anim. Sci. 28:82-86.

Barrow G.I. \& Feltham R.K.A. 1993. Cowan and Steel's Manual for the Identification of Medical Bacteria. $3^{\text {rd }}$ ed. Cambridge University Press, New York.

Carrasco L., Segalés J., Bautista M.J., Gómez-Villamandos J.C., Rosell C., Ruiz-Villamor E. \& Sierra M.A. 2000. Intestinal chlamydial infection concurrent with postweaning multisystemic wasting syndrome in pigs. Vet. Rec. 146:21-23.

Carter G.R., Chengapa M.M. \& Roberts A.W. 1995. Essentials of Veterinary Microbiology. $5^{\text {th }}$ ed. Williams and Wilkins, Philadelphia.

Clark E.G. 1997. Post-Weaning Multisystemic Wasting Syndrome. Proc. Annu. Meet. Am. Assoc. Swine Practioners, p.499-501.

Deplancke B. \& Gaskins H.R. 2001. Microbial modulation of innate defense: goblet cells and the intestinal mucus layer ${ }^{1-3}$. Am. J. Clin. Nutr. 73:1131-1141.

Driemeier D., Faccini G.S., Oliveira R.T., Colodel E.M., Traverso S.D. \& Cattani C. 2002. Silver staining combined with alcian blue and hematoxylin-eosin for the detection of Lawsonia intracellularis in swine proliferative enteropathy. Acta Histochem 104:285-287.

Duhamel G.E., Bargar T.W., Schmitt B.J., Molitor T.W. \& Lu W. 1991. Identification of parvovirus-like virus particles in intestinal crypt epithelial cells of pigs with diarrhea. J. Vet. Diag. Invest. 3:96-98.

Gaffney E. 1992. Carbohydrates, p.149-174. In: Prophet E.B., Mills B., Arrington J.B. \& Sobin L.H. (ed.), Laboratory Methods in Histotechnology. American Registry of Pathology, Washington, DC.

Genta R.M., Robason G.O. \& Graham D.Y. 1994. Simultaneous visualisation of Helicobacter pylori and gastric morphology: A new stain. Hum. Pathol. 25:221-226.

Gentsch J.R., Glass R.I., Woods P., Gouvea V., Gorziglia M., Flores J., Das B.K. \& Bhan M.K. 1992. Identification of Group A Rotavirus Gene 4 Types by Polymerase Chain Reaction. J. Clin. Microbiol. 30:13651373.

Gouvea V., Glass R.I., Woods P., Taniguchi K., Clark H.F., Forrester B. \& Fang Z.Y. 1990. Polymerase Chain Reaction amplification and typing of Rotavirus nucleic acid from stool specimens. J. Clin. Microbiol. 28:276-282.

Gouvea V., Allen J.R., Glass R.I., Fang Z.Y., Bremont M., Cohen J., McCrae M.A., Saif L.J., Sinarachatanant P. \& Caul O. 1991. Detection of Group B and C Rotaviruses by Polymerase Chain Reaction. J. Clin. Microbiol. 29:519-523.

Guedes R.M.C., Gebhart C.J., Winkelman N.L., Mackie-Nuss R.A., Marsteller T.A. \& Deen J. 2002. Comparison of different methods for diagnosis of porcine proliferative enteropathy. Can. J. Vet. Res. 66:99107.

Ha Y., Jung K., Choi C. \& Chae C. 2005. Outbreak of salmonellosis in pigs with postweaning multisystemic wasting syndrome. Vet. Rec. 156:583-584.

Hampson D.J. \& Trott D.J. 1999. Spirochetal diarrhea / porcine intestinal spirochetosis, p.553-562. In: Leman A.D., Straw B.E., Mengeling W.L., D'Allaire S. \& Taylor D.J. (ed.), Diseases of Swine, lowa State University Press, Ames.

Herbst W., Lange H., Danner K., Krauss H. \& Schliesser T. 1989. Electron microscopic virus detection in fecal samples from swine with enteric diseases between 1981 and 1987. Dtsch. Tierärztl. Wochenschr. 96:294-296.

Jensen T.K., Vigre H., Svensmark B. \& Bille-Hansen V. 2006. Distinction between porcine circovirus type 2 enteritis and porcine proliferative enteropathy caused by Lawsonia intracellularis. J. Comp. Pathol. 135:176-182.

Jiang X., Huang P.W., Zhong W.M., Farkas T., Cubitt D.W. \& Matson
D.O. 1999. Design and evaluation of a primer pair that detects both Norwalk- and Sapporo-like caliciviruses by RT-PCR. J. Virol. Methods 83:145-154.

Kim J. \& Chae C.A. 2004. A comparison of virus isolation, polymerase chain reaction, immunohistochemistry and in situ hybridization for the detection of porcine circovirus 2 and porcine parvovirus in experimentally and naturally co-infected pigs. J. Vet. Diag. Invest. 16:45-50.

Kim J., Ha Y., Jung K., Choi C. \& Chae C. 2004. Enteritis associated with porcine circovirus 2 in pigs. Can. J. Vet. Res. 68:218-221.

Kim H.J., Cho H.S., Cho K.O. \& Park N.Y. 2006. Detection and molecular characterization of porcine enteric caliciviruses in Korea genetically related to Sapovirus. J. Vet. Med. B. 53:155-159.

Lawson G.H. \& Gebhart C.J. 2000, Proliferative enteropathy. J. Comp. Pathol. 122:77-100.

Martinéz M.A., Alcalá A.C., Carruyo G., Botero L., Liprandi F. \& Ludert J.E. 2006. Molecular detection of porcine enteric caliciviruses in Venezuelan farms. Vet. Microbiol. 116:77-84.

Moxley R.A. \& Duhamel G.E. 1999. Comparative pathology of bacterial enteric diseases of swine. Adv. Exp. Med. Biol. 473:83-101.

Opriessnig T., Janke H. \& Halbur P.G. 2006. Cardiovascular lesions in pigs naturally or experimentally infected with porcine circovirus type 2. J. Comp. Pathol. 134:105-110.

Paul P.S. \& Stevenson G.W. 1999. Rotavirus and Reovirus. p.255-275. In: Leman A.D., Straw B.E., Mengeling W.L., D'Allaire S. \& Taylor D.J. (ed.), Diseases of Swine. lowa State University Press, Ames.

Paulovich F., Borowski S.M., Prates A.B.H., Driemeier D., Razia L.E., Pescador C.A., Corrêa A.M.R., Coutinho T.A. \& Barcellos D.E.S.N. 2004, Avaliação da patogenicidade de amostras de Brachyspira pilosicoli através de técnicas histopatológicas convencionais e por imuno-histoquímica. Pesq. Vet. Bras. 24:144-148.

Radhakrishnan V.V., Mathai A., Radhakrishnan N.S., Rout D. \& Sehgal S. 1991. Immunohistochemical demonstration of mycobacterial antigens in intracranial tuberculoma. Indian J. Exp. Biol. 29:641-644.

Rosell C., Segalés J., Plana-Durán J., Balasch M., Rodriguez-Arrioja G.M., Kennedy S., Allan G.M., McNeilly F., Latimer K.S. \& Domingo M. 1999. Pathological, immunohistochemical, and in-situ hybridization studies of natural cases of postweaning multisystemic wasting syndrome (PMWS) in pigs. J. Comp. Pathol. 120:59-78.

Schauser K., Olsen J.E., Larsson L.I. 2004. Immunocytochemical studies of Salmonella Typhimurium invasion of porcine jejunal epithelial cells. J. Med. Microbiol. 53:691-695.

Schwartz K.J. 1999. Salmonellosis. p.535-551. In: Leman A.D., Straw B.E., Mengeling W.L., D'Allaire S. \& Taylor D.J. (ed.), Diseases of Swine. lowa State University Press, Ames.

Segalés J., Fernandez-Salguero J.M., Fructuoso G., Quintana J., Rosell C., Pozo J., De Arriba M. L., Rubio P. \& Domingo M. 2001. Granulomatous enteritis and lymphadenitis in Iberian pigs naturally infected with Lawsonia intracellularis. Vet. Pathol. 38:343-346.

Segalés J. \& Domingo M. 2002. Postweaning multisystemic wasting syndrome (PMWS) in pigs: A review. Vet. Q. 24:109-124.

Segalés J., Rosell C. \& Domingo M. 2004. Pathological findings associated with naturally acquired porcine circovirus type 2 associated disease. Vet. Microbiol. 98:137-149.

Sorden S.D., Harms P.A., Nawagitgul P., Cavanaugh D. \& Paul P.S. 1999. Development of a polyclonal-antibody-based immunohistochemical method for the detection of type 2 porcine circovirus in formalin-fixed, paraffin-embedded tissue. J. Vet. Diag. Invest. 11:528530.

Sorden S.D. 2000. Update on porcine circovirus and postweaning multisystemic wasting syndrome (PMWS). Swine Health Prod. 8:133136.

Wang Q., Constantini V. \& Saif L.J. 2007. Porcine enteric caliciviruses: Genetic and antigenic relatedness to human caliciviruses, diagnosis and epidemiology. Vaccine 25:5453-5466. 